\title{
SCAN QR CODE UNTUK MENGENAL BENDA-BENDA BERSEJARAH DI MUSEUM
}

\author{
Gerlan A. Manu, ST, MKom ${ }^{1}$, Jhon Enstein S,Kom, MCs ${ }^{1}$ \\ ${ }^{1}$ Pendidikan Informatika, STKIP Citra Bina Nusantara, Kupang NTT \\ gerlanmanu@cbn.ac.id, enstein_j17@yahoo.com
}

\begin{abstract}
Abstrak
QR Codes merupakan pengembangan atau perubahan bentuk kode batang atau barcode dari satu dimensi menjadi dua dimensi, dengan kemampuan menyimpan data lebih besar dibanding kode batang atau barcode. QR Code dapat menyimpan data dalam bentuk angka, huruf, dan symbol. Sehingga QR Code dapat digunakan untuk menyimpan URL laman suatu situs. Situs tersebut dapat berisi informasi tentang bahan ajar yang dapat digunakan guru dalam proses pembelajaran di kelas. QR Code dapat digunakan sebagai media pembelajaran di kelas pada sekolah-sekolah. Umumnya informasi tentang benda-benda bersejarah di Museum akan dapat diakses oleh pengunjung atau siswa sekolah jika melakukan perkunjungan langsung ke Museum. Siswa dapat mengakses informasi tentang benda-benda bersejarah tersebut saat sekolahnya berkunjung ke Museum. Setelah itu saat kembali ke sekolah akses informasi dapat dilakukan dengan melihat katalog atau artikel lainnya yang diperoleh saat kunjungan ke museum tersebut. Dengan QR Code, informasi tentang benda-benda bersejarah tersebut dapat langsung diakses oleh siswa dengan cara melakukan pindai (scan) QR Code. Maka secara langsung siswa akan diantarkan pada URL laman situs yang berisi tentang benda bersejarah tersebut. Penelitian ini menghasilkan prototype sistem yang menjelaskan tentang alur penggunaan QR Code untuk mengenal benda benda bersejarah di Museum.
\end{abstract}

Kata Kunci : QR Codes, Media Pembelajaran, Benda Bersejarah, Museum

\section{PENDAHULUAN}

$Q R$-Codes adalah pengembangan dari barcodes. $Q R$ Codes sering disebut sebagai dua dimensi barcodes. Diciptakan oleh Denso Wave, anak perusahaan Toyota, yang digunakan untuk melacak komponen otomotif. Tidak seperti barcode yang hanya dapat menyimpan data huruf dan angka, QR Code dapat menyimpan data angka, huruf dan symbol. Oleh karena itu QR Code dapat menyimpan data seperti URL laman situs tertentu. [4]

Dewasa ini terdapat aplikasi pemindai (scan) QR-Code yang dapat diunduh secara gratis melalui smartphone Android atau IOS. Beberapa diantaranya seperti Kaywa Reader, BeeTagg, Qrafter, Bakodo, QRReader, i-nigma, TapReader, QRDroid dan ATTScanner. Atau aplikasi lainnya dapat diunduh dengan melakukan pencarian aplikasi dengan kata kunci " $Q R$ Codes Reader" atau " $Q R$ Code Scanner". Selain itu terdapat juga beberapa smartphone yang telah menyediakan fitur pemindai (scan) QR-Code.[5]

Dalam pembelajaran di kelas pada sekolah-sekolah, QR-Codes dapat digunakan sebagai games atau permainan. Siswa dapat dengan mudahnya melakukan pindai (scan) QR Code dan secara langsung ditampilkan informasi suatu laman situs berdasarkan data URL yang disimpan oleh QR Code tersebut. Dengan ini guru tidak perlu lagi mengecek setiap siswanya, apakah sudah memasukan alamat suatu situs dengan benar.

Benda-benda bersejarah di Museum hanya dapat diakses informasinya melalui 
perkunjungan ke Museum atau melihat katalog dari benda-benda bersejarah tersebut. Beberapa katalog dicetak oleh manajemen Museum dan dibagi secara gratis pada setiap pengunjung. Juga terdapat website Museum untuk memperkenalkan koleksi benda-benda bersejarah tersebut kepada masyarakat umum. Setiap laman website tersebut memiliki URL (Unifrom Resource Locator) yang menunjukkan alamat dari lama tersebut. URL tersebut dapat dibuatkan QR Code. Kemudian hasil dari QR Code ini dapat dimanfaatkan untuk beberapa hal, salah satunya adalah sebagai Media Pembelajaran di Sekolah.

Hasil dari penelitian ini adalah prototype sistem yang menjelaskan tentang alur penggunaan QR Code untuk mengenal benda - benda bersejarah di Museum. Prototype ini dapat dikembangkan lagi menjadi prototype lanjutan atau bahkan menjadi sistem yang sudah dapat digunakan.

\section{METODE PENELITIAN}

Metode penelitian pada penelitian ini adalah dengan melakukan studi kepustakaan dan perancangan sistem. Adapun perancangan sistem menggunakan metode Evolutionary Prototype, yaitu prototype yang secara terus-menerus dikembangkan hingga prototype tersebut memenuhi fungsi dan prosedur yang dibutuhkan oleh sistem [1][3].

Langkah - langkah dalam metode Evolutionary Prototype yang dibahas dalam penelitian ini adalah sebagai berikut :

1. Analisa Kebutuhan, melakukan analisa atas kebutuhan sistem dalam hal ini yaitu memperkenalkan benda-benda ber-sejarah di Museum kepada pengunjung museum, atau pelajar melalui smartphone

2. Membuat Prototype, dibuatkan prototype sistem sesuai dengan analisa sistem langkah 1. Adapun perancangan sistem ditampilkan pada Gambar 1.

3. Menyesuaikan Prototype, dilakukan uji coba sistem apakah telah benar-benar sesuai dengan kebutuhan sistem. Jika tidak maka akan dilakukan analisa kebutuhan lagi, jika sesuai dilanjutkan ke langkah 4.

4. Menggunakan Prototype, sistem mulai dikembangkan dengan Prototype yang dibuat. Alur sistem yang dibuat ditampilkan pada Gambar 2.

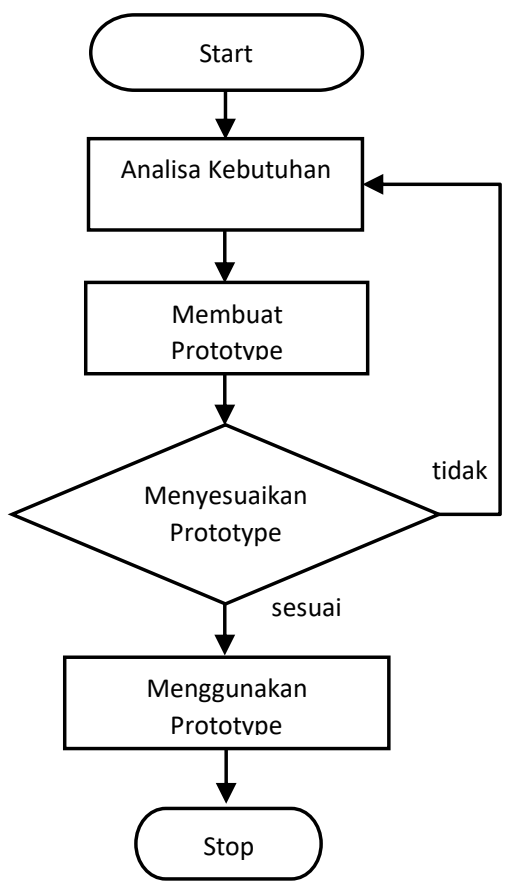

Gambar 1. Perancangan Sistem

Informasi tentang benda -benda bersejarah di Museum yang sebelumnya hanya dapat diakses dengan membaca katalog yang ada di museum atau sumber lainnya, melalui QR Code Informasi tersebut dapat dibaca dengan menggunakan smartphone para pengunjung masingmasing. Dengan memindai (scan) QR Code, para pengunjung akan diberikan informasi secara lengkap tentang benda-benda bersejarah yang dimaksud. Hal ini pun dapat dimanfaatkan dalam pembelajaran di kelas 
terkait dengan benda-benda bersejarah di Museum. Guru dapat menggunakan lembaran QR-Code sebagai media pembelajaran yang dapat dipindai (scan) para siswa di kelas. Hasil dari pindai (scan) QR Code ini tampil pada smartphone setiap siswa.

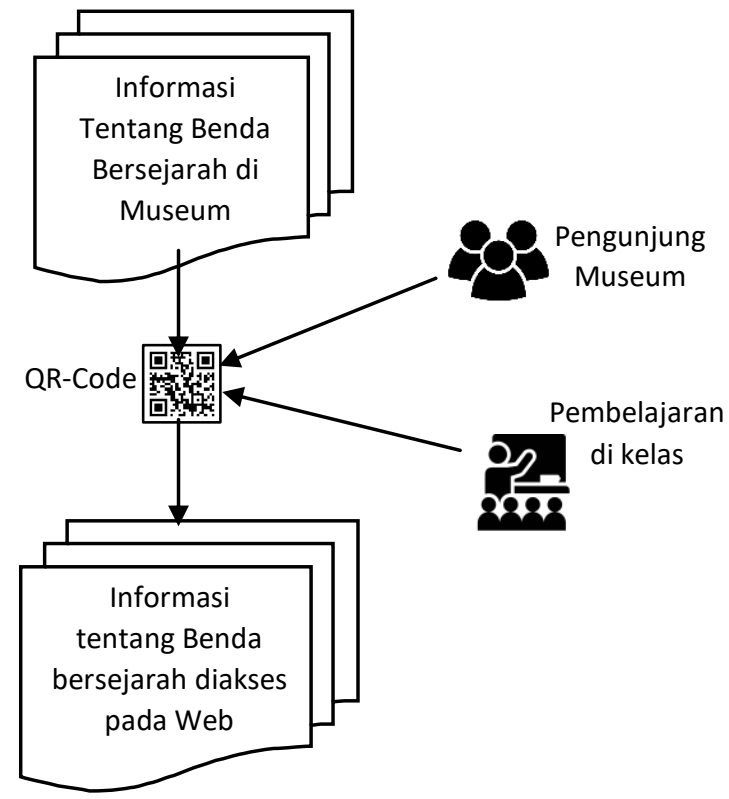

Gambar 2. Alur Sistem

\section{HASIL DAN PEMBAHASAN a. Analisa Kebutuhan}

Dalam proses ini dilakukan analisa kebutuhan sistem. Kebutuhan Sistemnya yaitu :

1. Katalog Benda-Benda Bersejarah yang ada di Museum

2. Video Benda-Benda Bersejarah yang ada di Museum

3. Foto/ Gambar Benda-Benda Bersejarah yang ada di Museum

\section{b. Membuat Prototype}

Dalam proses ini dirancang sebuah website berisi informasi detail tentang benda-benda bersejarah di Museum Prov NTT. Informasi tersebut dikutip dari Katalog dan Video yang diperoleh dari langkah 1. Analisa
Kebutuhan. Berikut adalah rancangan Prototype :

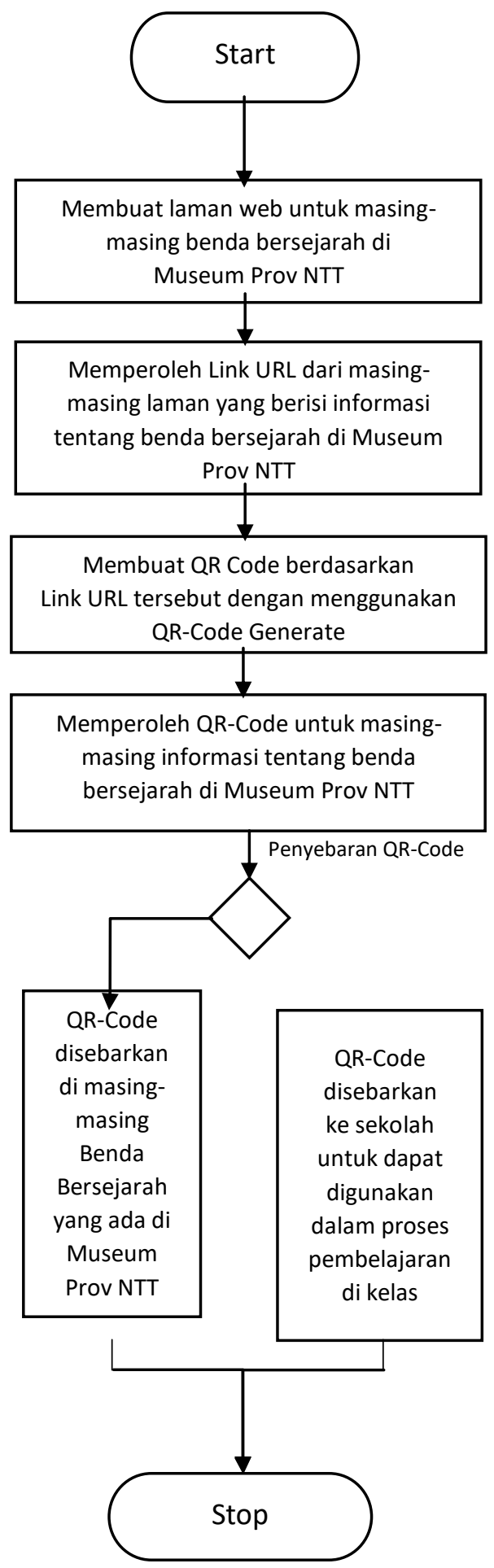

Gambar 3. Rancangan Prototype 
Setiap benda-benda bersejarah memiliki laman tersendiri. Masing-masing laman tersebut akan dibuatkan QR-Code menggunakan $Q R$-Code Generate.

Berikut adalah beberapa QR Code Generator yang dapat digunakan [2][6] :

1. https://qrcode.kaywa.com

2. https://www.qrstuff.com

3. https://delivr.com/qr-code-generator

4. https://beqrious.com/qr-codegenerator

5. http://zxing.appspot.com/generator

Setelah terbentuk QR-Code selanjutnya dilakukan penyebaran QR-Code untuk digunakan di Museum atau di sekolahsekolah yang membutuhkan.

Berikut adalah rancangan menu website yang akan menampilkan informasi tentang benda-benda bersejarah di Museum
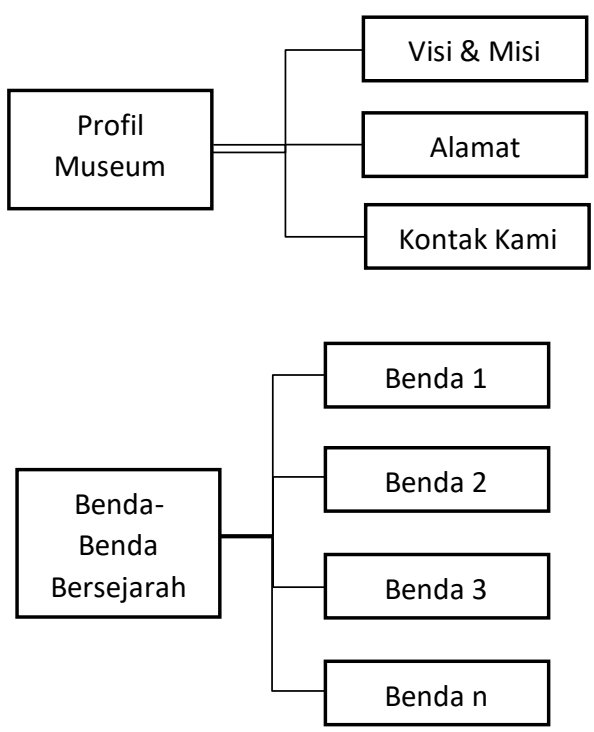

\section{Gambar 4. Struktur Menu Website}

Setiap menu website yang dirancang memiliki laman situs dan url tersendiri. Dengan menggunakan QR-Code Generator maka akan diperoleh QR-Code berdasarkan
Url laman situs untuk setiap benda-benda bersejarah tersebut.

c. Menyesuaikan Prototype

Pada proses ini dilakukan uji coba terhadap QR-Code yang sudah dibentuk. Scan QRCode dapat menggunakan aplikasi Scan QRCode yang dapat didownload pada smartphone Android maupun IOS. Jika terjadi kesalahan atau tidak valid informasi yang ditampilan pada saat dipindai (scan) maka kembali pada proses pertama yaitu analisa kebutuhan.

d. Menggunakan Prototype

Pada proses ini prototype telah siap untuk dikembangkan menjadi prototype lanjutan atau dibentuk menjadi sistem yang siap digunakan. QR-Code yang sudah dibentuk dapat diletakkan pada papan nama benda benda bersejarah di Museum atau diperbanyak dan dipublikasi, sehingga QRCode ini dapat digunakan oleh sekolahsekolah untuk pembelajaran benda-benda bersejarah secara langsung di kelas.

\section{KESIMPULAN}

Penelitian ini menggunakan metode Evolutionary Prototype yaitu prototype yang secara terus-menerus dikembangkan hingga prototype tersebut memenuhi fungsi dan prosedur yang dibutuhkan oleh sistem. Pada penelitian ini menghasilkan prototype rancangan sistem Scan QR-Code untuk Pembelajaran Benda-Benda Bersejarah di Museum. Prototype yang dihasilkan dapat dikembangkan lagi menjadi prototype lanjutan atau juga dapat digunakan untuk perancangan sistem.

\section{DAFTAR PUSTAKA}

[1] Bidgoll Hossein, The Internet Encyclopedia Volume 3, New Jersey : Jhon Wiley \& Sons Inc, 2004

[2] Dutson Phil, Creating $Q R$ and Tag Codes, Indianapolis : Sams Publishing, 2013 
[3] Guida Giovanni, Gianfranco Lamperti, Marina Zanella, Software Prototyping in Data and Knowledge Engineering, Italia : Springer Science+Business Media Dordrecht, 1999

[4] Pengertian Barcode dan QR Code. http://indotekmultimedia.com/pengerti an-barcode-dan-qr-code

[5] Price Kella, QR-Codes for Trainers, United States : American Society for Training and Development, 2013

[6] Waters Joe, $Q R$ Codes for Dummies, New Jersey : Jhon Wiley \& Sons Inc, 2012 